\title{
Financial Performance Trends and Corporate Responsibility Incentives in a Group of Support Services in Constanța County, Romania
}

\author{
Kamer Ainur AIVAZ *
}

\begin{tabular}{l}
\hline \multicolumn{1}{c}{ A R T I C L E I N F O } \\
\hline Article history: \\
Accepted April 2021 \\
Available online April 2021 \\
\hline JEL Classification \\
G30, M14, N74, P54 \\
Keywords: \\
Financial performance, Support \\
services, Principal component \\
analysis, Corporate responsibility, \\
Corporate financial performance \\
\hline
\end{tabular}

\begin{abstract}
A B S T R A C T
The current study enhances the empirical knowledge of the different interdependencies between corporate social responsibility (CSR) mechanisms and corporate financial performance, (CSP) from an interesting group of support services for businesses in Romania. We observe the trends of the financial indicators reported by companies that developed support services for other businesses and explore interesting correlations between the investigated indicators with the PCA analysis. The results point to a strong causality link between CSP and CSR, which encourages further analysis in other operational sectors.
\end{abstract}

(C) 2021 EAI. All rights reserved.

\section{Introduction}

Recently, the strategies and regulations in force in the business field increasingly require companies to improve their social and environmental performance (Lubin and Esty, 2012; Meier and Cassar, 2018), a performance which is assessed through corporate social responsibility practices (CSR) (Theodoulidis et al., 2017).

These practices are or should be a current concern for business support service activities, where economic entities' initiatives or companies' CSR annual reports demonstrate the increasing commitment of the firms to responsible business practices. Although there are many examples of successful CSR pursuits, there are still many situations in which the activities of the companies do not comply with responsible behaviors.

In the Romanian activity sector, where each company chooses, when it is set up, a main activity that broadly defines its future operations, there is an operational subcategory that encompasses in an interesting way many of the activities of interest to the principles of sustainability. At a time when business orientation is competing towards promoting a balanced work environment, when attention to the environment is increasingly stringent, or when innovation is a key element to performance, operational diversity classified as business support services sparks a particular interest.

These considerations led to doing this research for the group of business support service activities (Classification of the Activities in the National Economy/CAEN 8299), which brings together extremely varied activities. The study aimed to understand corporate financial performance (CFP) in the context of the concerns for CSR practices, based on the premise that simply investing in CSR is insufficient to improve performance and recognizing that a broader vision should be developed in order to achieve this goal. Also, the impetus triggered by previous studies to further develop comparative and explicative studies that can support with empirical knowledge the development trends in Eastern Europe (Munteanu, 2020a), drives the current study to present a new perspective from a group of support activities in the coastal region of Romania.

\section{Literature review}

According to the specialized literature, the firms' involvement in sustainable development programs that led to the companies' development (Eccles et al., 2014), also produced an improvement in their relations with CSR stakeholders by increasing trust and reciprocity, resulting in an increase in CFP (Barnett, 2007; Barnett and Salomon, 2012). Notwithstanding all of these advantages, carrying out CSR activities also involves costs that can lead to a competitive disadvantage compared to competitors who do not allocate 
funds and time for them (Barnett and Salomon, 2006, 2012; Friedman, 1970). Despite the extensive literature on the CSR-CFP relationship, research is still far from finding a common denominator or a unitary vision of this relationship. A number of previous studies have revealed mixed, often contradictory results (Garay and Font, 2012; Theodoulidis et al., 2017).

According to the stakeholder theory, CSR's impact on CFP can be both positive and negative, as stakeholders may or may not reward firms that perform well in terms of CSR. Obviously, when companies get poor results in this direction, the reaction of these parties has no impact on performance. In other words, CSR costs are not outweighed by the gains in CFP unless CSR directly demonstrates its effectiveness.

Previous research, based on the stakeholder theory and, respectively, on the theory of the effect on companies, has argued that the impact of CSR on CFP can have either a U-shape (Park and Lee, 2009; Barnett and Salomon, 2012), or an inverted U-shape (Bowman and Haire, 1975). However, these studies do not consider that companies with poor CSR performance can really be penalized by the stakeholders, whose negative attitudes towards such firms may be detrimental to their performance (Carlos and Lewis, 2018).

The U-shaped relationship represents two types of companies: those whose performance decreases when their CSR efforts increase, but at a level that does not allow them to reach and exceed the "threshold effect" (i.e., the stakeholders tend to sanction the relatively weak involvement in CSR); and those who exceed the "threshold effect", thus experiencing an increase in their performance. There are studies that support the idea that involvement in CSR programs is not in itself a condition for increasing CFP and that reaching a certain level of the responsible performance threshold must be met implicitly by the firms in order to improve their financial performance. In doing so, these studies challenge most existing studies that suggest the existence of a direct linear link between CSR and CFP, i.e., an increase (decrease) in CSR performance always leads to a better (worse) financial performance.

According to Freeman and Hasnaoui (2011), CSR has been defined in different ways and from several perspectives, being recognized as a multidimensional concept that encompasses both economic and judicial, ethical and philanthropic aspects (Carroll, 1999). According to Freeman's (1984) stakeholder theory, CSR is a concept that refers to the strategic orientation of the firms, capable of implementing socially and ecologically responsible actions, while at the same time pursuing their economic objectives (Russo and Perrini, 2010; Goffi et al., 2018). These firms will take into account all the parties involved, their goals, trying to generate value without denying the interests of any of them (Carroll and Shabana, 2010; Freeman et al., 2004).

Stakeholder pressure is one of the main reasons why the companies carrying out support service activities deal with CSR practices (Farmaki, 2018; Iyer and Jarvis, 2019). Indeed, the theory suggests that the stakeholders control the resources that may be important to companies and, consequently, the relationships established with them should be properly managed, so as to ensure the revenues and profits pursued by the firms (Salancik and Pfeffer, 1978; Wang et al., 2016). Also, the stakeholder and managerial perspectives on conformity to regulations concerning financial or non-financial results (Munteanu and Mirea, 2017) strongly resonate in assessing the CSR-CFP relationship.

In this context, we have considered it appropriate to analyze the dynamics of the financial performance indicators for companies that carry out business support activities and which deal in a consistent manner with corporate social responsibility practices.

\section{Methodology}

The CAEN class analyzed (8299), "Other business support activities", is very heterogeneous, and can include a wide range of activities. The standard classification refers to the following activities: a. ensuring full reports and shorthand recordings of live legal proceedings and subsequent transcription of recorded materials, such as: recording services or shorthand recording of court proceedings and public shorthand services; b. real-time (i.e., simultaneous) closed-circuit recording of live TV broadcasts of meetings, conferences, etc.; c. barcode generating services; d. barcode printing services; e. fundraising based on a fee or a contract organization services; f. repossession services; g. coin collection from parking meters services; $h$. activities of independent sellers at auctions; i. administration of loyalty programs; j. other support activities usually provided to enterprises, not classified elsewhere.

In Romania's coastal area, represented mostly by Constanta County, the companies which have opted for this CAEN classification group as their main activity have interesting features. The companies subscribed to the 8299 group in Constanta carry out labor protection activities, professional training support activities, marketing or promotion services, innovative design services or design in the IT field, logistics services or services in fields with a high degree of activities' specialization, such as support services for the creation of wind farms or the maritime sector.

The research was performed in two stages. In the first stage we have provided a statistical description of the analyzed indicators, and in the second stage we have applied the method of Principal Component Analysis in order to highlight the statistical links between the variables, the similarities and differences between the analyzed statistical units (firms). 


\section{Description of data}

The present study aims to perform a dynamic financial analysis of the category of support activities for enterprises in Constanta County in the period 2010-2019. In order to achieve this objective, the financial indicators reported by the companies in their annual financial statements and publicly available on the website of the Romanian Ministry of Public Finance are analyzed. In order to address the challenges of choosing the relevant financial indicators for the current analysis (Munteanu, 2020b), only the active firms were considered, with positive or negative financial results and reported operational results.

Seen as a whole, the business sector has been continuously expanding in Constanta County in the last decade. One of the interesting features of the CAEN 8299 group is that even though the number of companies that opted for this main category of activity experienced a relatively stable trend, the general profitability indicators, but also fixed assets, shareholders' equity and staff costs have been increasing, as can be seen in table no.1.

Table 1. Fixed assets, shareholders' equity, staff costs, number of companies for the CAEN 8299 group

\begin{tabular}{rrrrr}
\hline Years & Fixed assets & $\begin{array}{c}\text { Shareholders' } \\
\text { equity }\end{array}$ & Staff costs & $\begin{array}{c}\text { Number of } \\
\text { companies }\end{array}$ \\
\hline 2010 & 177254.32 & 190964.04 & 59680.03 & 147 \\
\hline 2011 & 188362.28 & 201337.36 & 75374.51 & 140 \\
\hline 2012 & 175855.89 & 173320.35 & 77884.04 & 168 \\
\hline 2013 & 240647.36 & 195126.26 & 96927.3 & 149 \\
\hline 2014 & 262051.18 & 200143.53 & 119427.85 & 157 \\
\hline 2015 & 265511.36 & 238285.34 & 139772.55 & 152 \\
\hline 2016 & 292202 & 249701.48 & 147522.71 & 153 \\
\hline 2017 & 321949.56 & 327894.32 & 193329.63 & 150 \\
\hline 2018 & 363417.48 & 381596.93 & 234604.91 & 151 \\
\hline 2019 & 360905.35 & 467690.23 & 294679.03 & 147 \\
\hline & & & &
\end{tabular}

New interesting observations can be deduced from the analysis of Table 1. The significant and increasing value of the average fixed assets for the CAEN 8299 group demonstrates a predilection for investing of the companies in the analyzed period. In terms of structure, however, the companies subscribed to this field of activity are very different in terms of undertaken operations, and their financial indicators show a significant degree of heterogeneity.

While some companies reported zero values of their fixed indicators, the average value of the financial indicator calculated at the group level was increased by the significant levels of reporting from a small number of companies, as evidenced by the very high level of kurtosis.

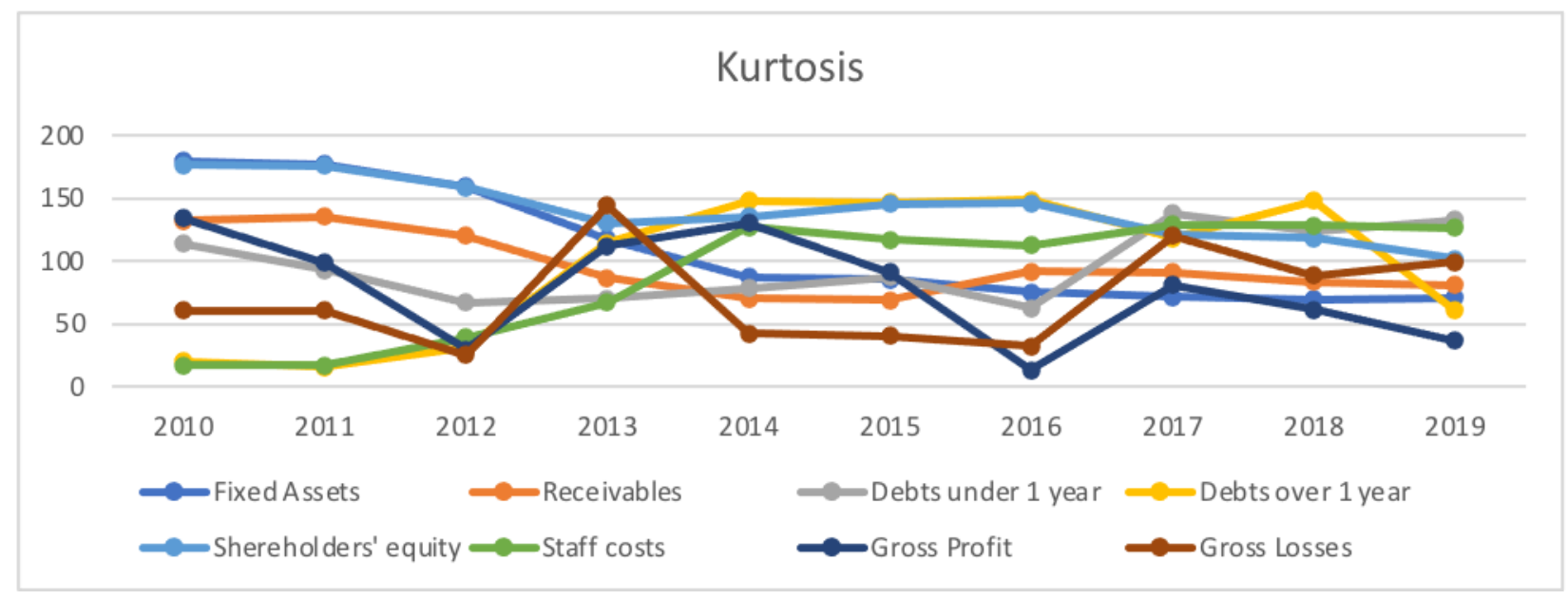

Figure 1. Kurtosis of financial indicators for CAEN 8299

As for the asymmetry of the distributions, there is a pronounced asymmetry to the right, this result indicating that most companies have high values of their indicators. Basically, at the level of the CAEN 8299 
group, the losses or reduced values recorded for some financial indicators by some companies are compensated by the high values recorded by the other companies.

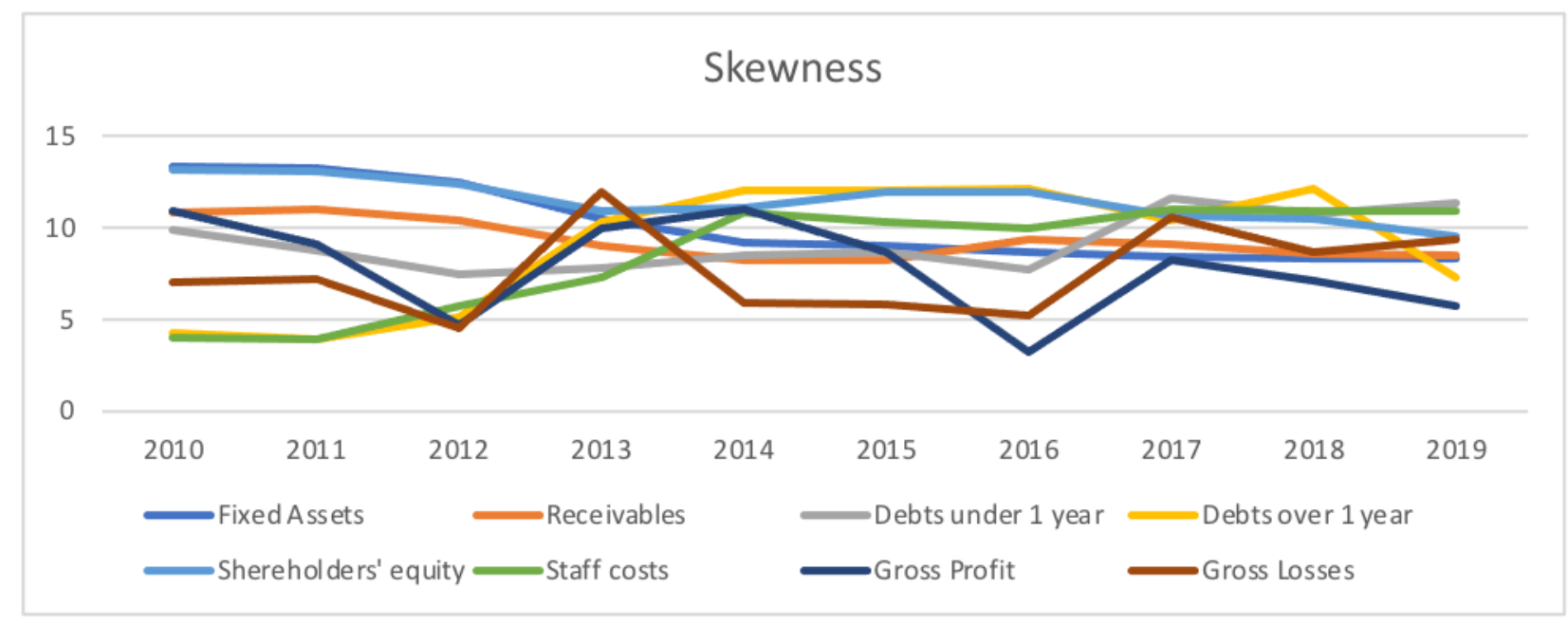

Figure 2. Skewness of financial indicators for CAEN 8299

Furthermore, the average positive and increasing value at the level of the group of the fixed assets indicates an activity oriented towards profitability and efficiency of the companies that carry out their main activities within this group. The high and increasing value of the salaries' expenses reported for this group supports the interest towards expanding the research.

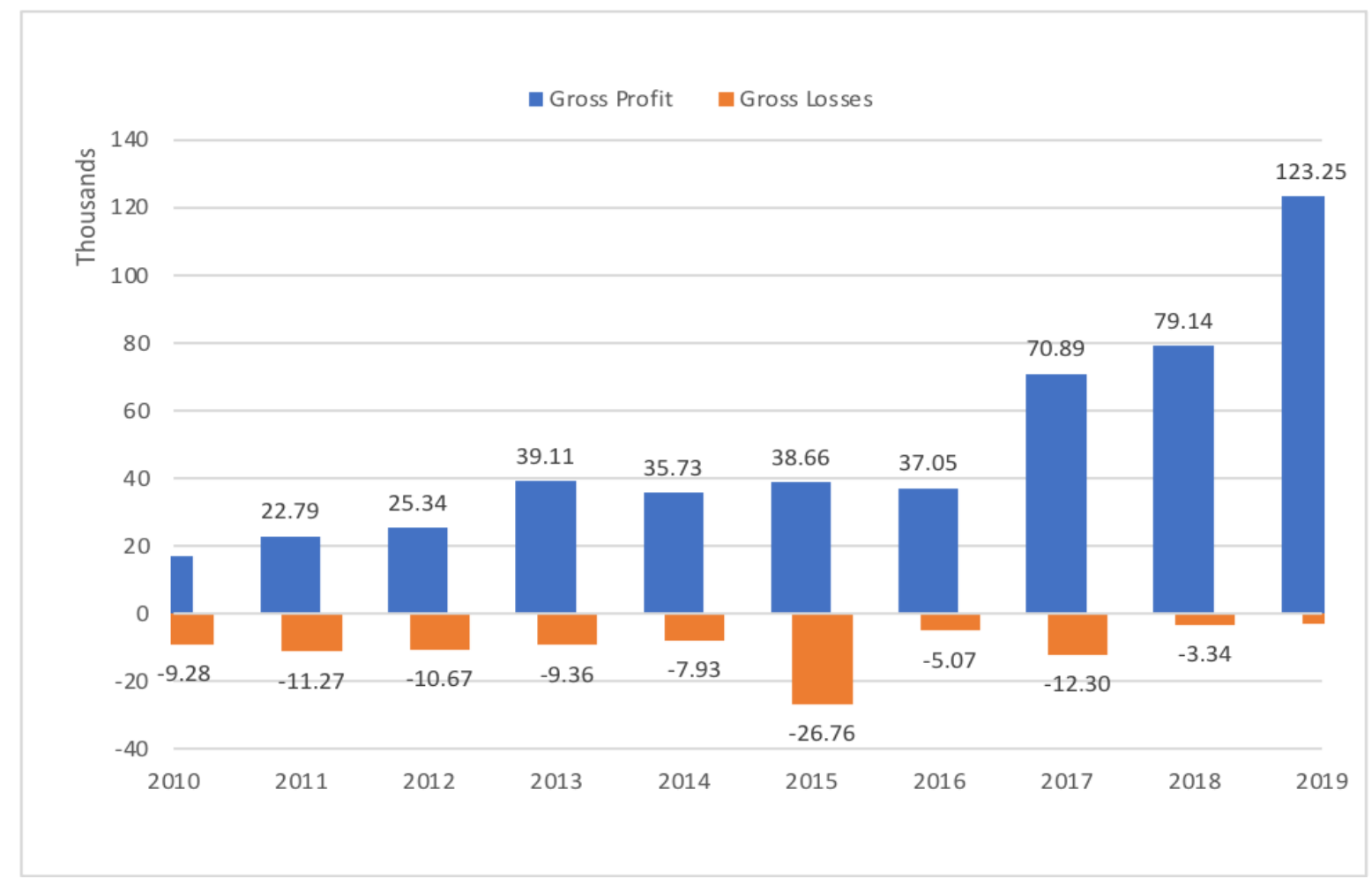

Figure 3. Gross profit and gross losses for CAEN group 8299

Figure 3 shows the dynamics of the average values of gross profits and, respectively, of gross losses reported by companies carrying out activities within the CAEN 8299 group. As can be seen from the graphical representation, the average values of the profits reported by the companies in this field of activity outperform the average losses.

The evolution in its dynamics presented in figure 4 indicates an increased degree of profitability of the support activities for enterprises. The number of companies that reported losses compared to the companies that reported profits decreased considerably, from 77 companies in 2010 to 33 companies in 2019. 


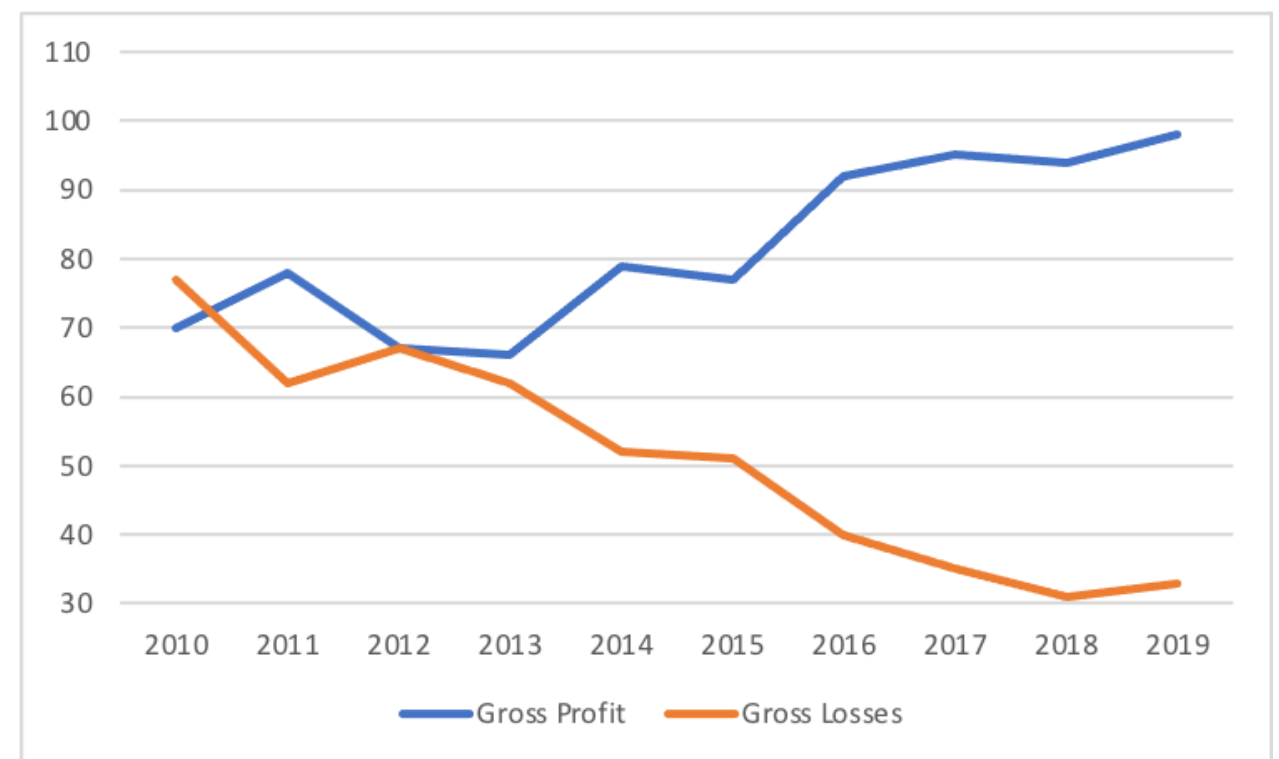

Figure 4. Dynamics of the number of companies that recorded profit and losses at the level of the CAEN group 8299

The decreasing number of companies may be a result of the fact that the companies that reported losses either ceased their activity or underwent restructuring, or found ways to revive their activity and, thus, became profitable.

At the same time, the companies that recorded a profit had a positive dynamics, their number increasing from 70 companies in 2010 to 98 companies in 2019.

The situation can have various explanations, a possible explanation being found in the multitude of types of activities subordinated to this CAEN group, activities that were able to adapt to the changes in the economic structure of the area and to the requirements imposed by a responsible and sustainable development.

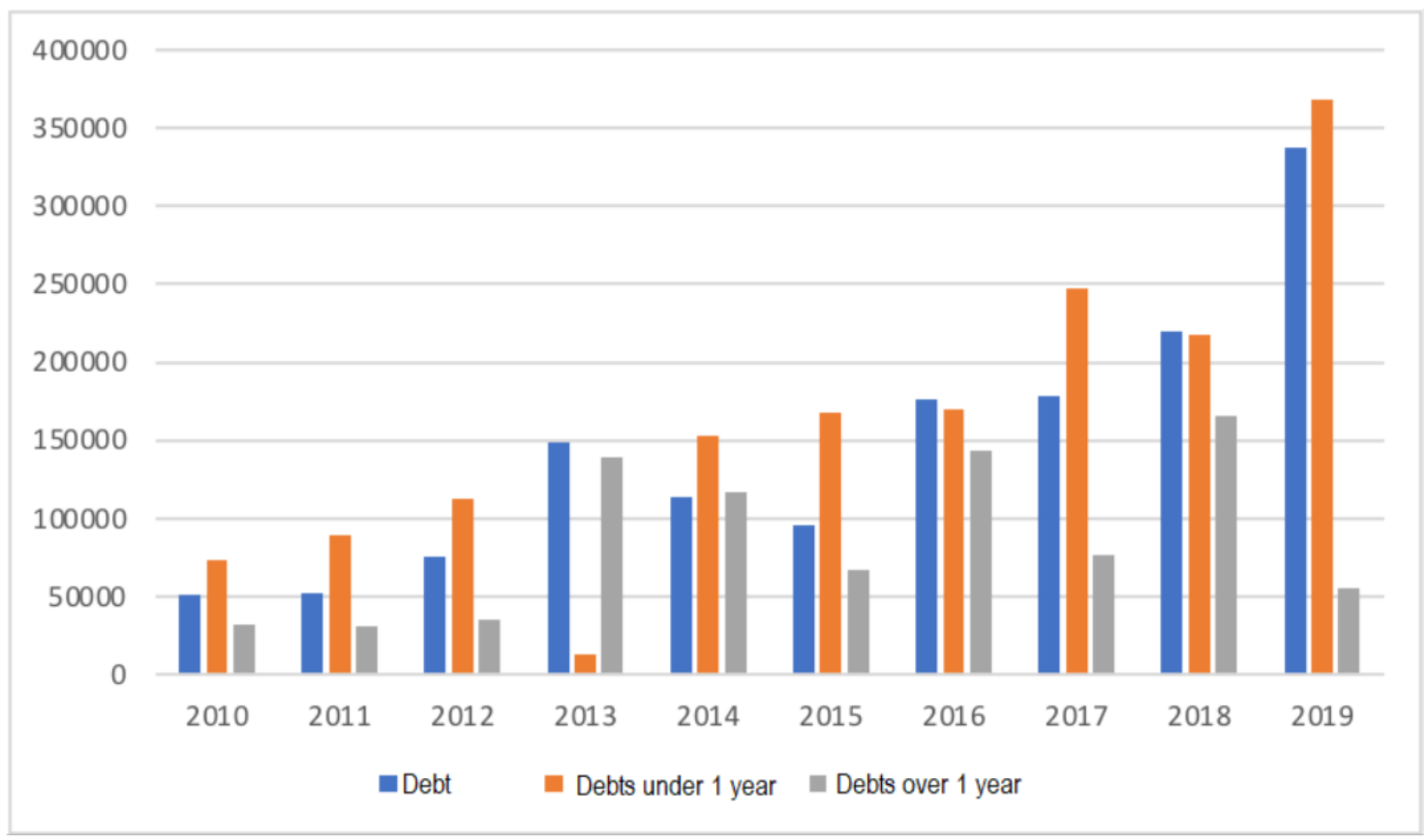

Figure 5. Dynamics of receivables, debts under 1 year and debts over 1 year

Figure 5 shows the dynamics of the average values of the receivables, short-term debts and longterm debts reported by the companies operating in the analyzed field of activity. The option of analyzing the average values allows reaching conclusions on the general conduct of the operations carrying out the main activities subscribed to CAEN code 8299. Regarding the receivables, the evolution in the reference period shows a general upward trend, with the exception of the year 2013, when the value of the indicator is extremely low. The analysis of the evolution of the receivables observed in correlation with the evolution of short-term debts presents similarities. In contrast, the evolution of the average indicators regarding long- 
term debt has fluctuated over time, with no predictable evolution of this result. The average values of longterm debt show significant fluctuations from one year to another, which indicates the need to deepen the analysis in a subsequent study.

\section{Findings and considerations}

The correlation matrix presents the values of the correlation coefficients between the variables considered two by two, allowing the assessment of the possibility of applying the Principal Component Analysis/PCA.

Table 2. The correlation matrix

\begin{tabular}{|c|c|c|c|c|c|c|c|}
\hline & $\begin{array}{l}\text { Fixed } \\
\text { assets }\end{array}$ & Receivables & $\begin{array}{l}\text { Debts } \\
\text { under } \\
1 \text { year }\end{array}$ & $\begin{array}{l}\text { Debts over } \\
1 \text { year }\end{array}$ & $\begin{array}{l}\text { Sharehold } \\
\text { ers' equity }\end{array}$ & Staff costs & $\begin{array}{l}\text { Gross } \\
\text { profit }\end{array}$ \\
\hline Fixed assets & 1 & & & & & & \\
\hline Receivables & 0.902 & 1 & & & & & \\
\hline Debts under 1 year & 0.732 & 0.811 & 1 & & & & \\
\hline Debts over 1 year & 0.640 & 0.378 & 0.012 & 1 & & & \\
\hline $\begin{array}{l}\text { Shareholders' } \\
\text { equity }\end{array}$ & 0.905 & 0.973 & 0.837 & 0.337 & 1 & & \\
\hline Staff costs & 0.944 & 0.981 & 0.818 & 0.424 & 0.991 & 1 & \\
\hline Gross profit & 0.850 & 0.952 & 0.883 & 0.190 & 0.980 & 0.965 & 1 \\
\hline $\begin{array}{l}\text { Number of } \\
\text { companies }\end{array}$ & -0.816 & -0.578 & -0.418 & -0.688 & -0.547 & -0.623 & -0.497 \\
\hline
\end{tabular}

The correlation matrix indicates strong and interesting links between the analyzed indicators. Fixed assets are strongly correlated with all the achieved indicators, having a directly proportional connection with most indicators, except for the number of companies with which they are in an inverse proportionality relationship (-0.816). The negative link between the indicators number of companies and fixed assets $(-8,816)$, and debts over 1 year $(-0,688)$ suggests a predilection for investing in fixed assets of a small number of companies in the CAEN group 8299. The graphic representation of the fluctuating dynamics of average debts over 1 year, correlated with the increasing value of fixed assets in table no. 1 seems to confirm this hypothesis. At the same time, the strong link between long-term debt and fixed assets (0.640) and the lack of significant links between debts over 1 year and other indicators reinforces the idea that there is a high probability that long-term loans contracted by companies are invested in fixed assets with the role of increasing the prospects of continuing the activity.

Staff costs do not have a significant connection with the number of companies operating in the CAEN 8299 subgroup. However, they do have a strong direct link in relation to fixed assets (0.944), with the increasing value of the receivables (0.981), as well as with the profitability indicators (0.965).

In order to test the hypothesis of independence of the studied variables we used the $\chi^{2}$ statistics, formulating two hypotheses: $\mathrm{H}_{0}$, in which we admitted that there is no statistical link between the two variables and $\mathrm{H}_{1}$, in which we admit the existence of the link. The $\chi^{2}$ statistics calculated based on the initial data is presented in the KMO output and Bartlett's Test.

The calculated value of the test statistic $\chi^{2}=120.195$ indicates an appropriate level of significance (Sig. $=0.000<0.05$ ), which shows that there are statistical links between the two variables. In this situation, the factor analysis can be applied to the considered data, the results obtained by PCA being considered good.

Table 3. Communalities

\begin{tabular}{llc}
\hline \multicolumn{1}{c}{ Communalities } & Initial & \multicolumn{1}{c}{ Extraction } \\
\hline Fixed assets & 1 & 0.993 \\
Receivables & 1 & 0.952 \\
Debts under 1 year & 1 & 0.879 \\
Debts over 1 year & 1 & 0.926 \\
Shareholders' equity & 1 & 0.973 \\
Staff costs & 1 & 0.985 \\
Gross profit & 1 & 0.983 \\
Number of companies & 1 & 0.814 \\
\hline
\end{tabular}

Extraction Method: Principal Component Analysis. 
The statistical significance of the links between the indicators analyzed using the PCA method is supported by the high values from the table of communalities, these being strongly correlated with the factorial axes. Communalities for a variable is the percentage of variance of a given variable explained by the factors extracted using PCA. In other words, the communality also indicates the link's strength for each analyzed variable, using as predictors all the other variables, concentrated in the factorial axes system. In the communalities graph, SPSS labels this column as "initial" communalities. "Extraction" communalities represent the percentage of variance in a given variable explained by the factors which are extracted.

Thus, the variation of gross profit is explained in a proportion of $98.3 \%$ by the extracted factors (in our case the variables: fixed assets, debts under 1 year, debts over 1 year, shareholders' equity, staff costs) through PCA.

Table 4. Total Variance Explained

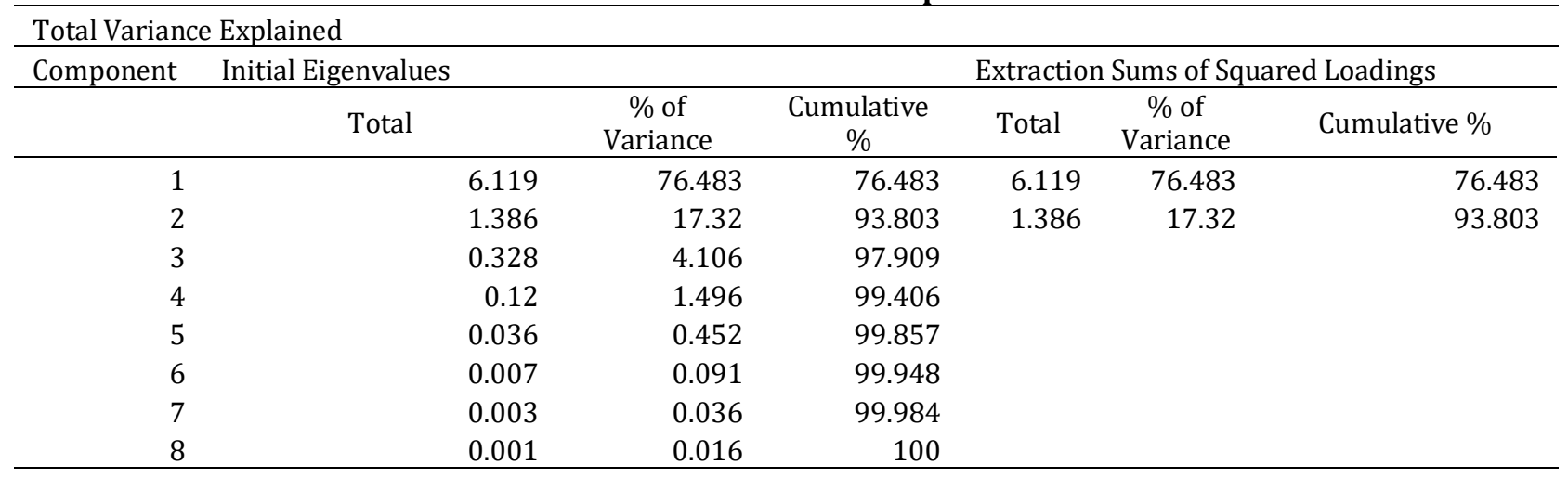

Extraction Method: Principal Component Analysis.

The most important differences between the analyzed companies from the point of view of the analyzed indicators are highlighted by the first factorial axis, its explanation being sufficient considering the high weight of the variance explained by this factorial axis $(76.48 \%)$.

\section{Conclusions}

The results of this study are based on a complex database which covers all the companies carrying out support activities for enterprises and capture the financial dynamics of the business in this activity subsector over an extensive, 10-year period. Sustainable development is an increasingly common topic in the current period, so that the prerogatives of performance and operational continuity require attention to study for a better future. The present analysis is carried out on a diverse sample of companies that have common objectives, oriented to support other businesses, to identify innovative solutions to support their performance prospects, to professionalize the workforce available on the market, to streamline outsourced logistics services or provide various personnel related services.

The orientation towards the profitability of the beneficiaries by the nature of the provided services, while also pursuing one's own positive results, conveys to the present analysis a distinct note of interest and relevance.

In a general sense, the predilection for creating a sustainable material base seems to confirm the prospects of continuity and profitability in the case of companies that offer support services to other entities. Although the number of companies operating in this economic subcategory is not very large at the level of Constanța City, it still includes a number of strong actors on the local economic scene, being representative for a number of companies with an active role in promoting the spirit of innovation and care for the environment.

The importance of the results is proved by the interesting evolutions of the analyzed indicators. Thus, although the number of companies did not fluctuate significantly over time, the financial indicators reported on average in the CAEN 8299 group experienced spectacular increases. Thus, the inclination towards investment and implicitly towards the development on the principle of continuity of activity, are suggested by the increase in the average indicators of fixed assets. If a parallel is drawn between the increase in fixed assets and the decrease of long-term debts, retaining the shareholders' equity increase fund, then one can outline an interesting observation in the direction of creating sustainable material bases by using one's own investment sources, to the detriment of external sources.

The current studies rings empirical evidence that CSP strongly suports the development of CRS. 


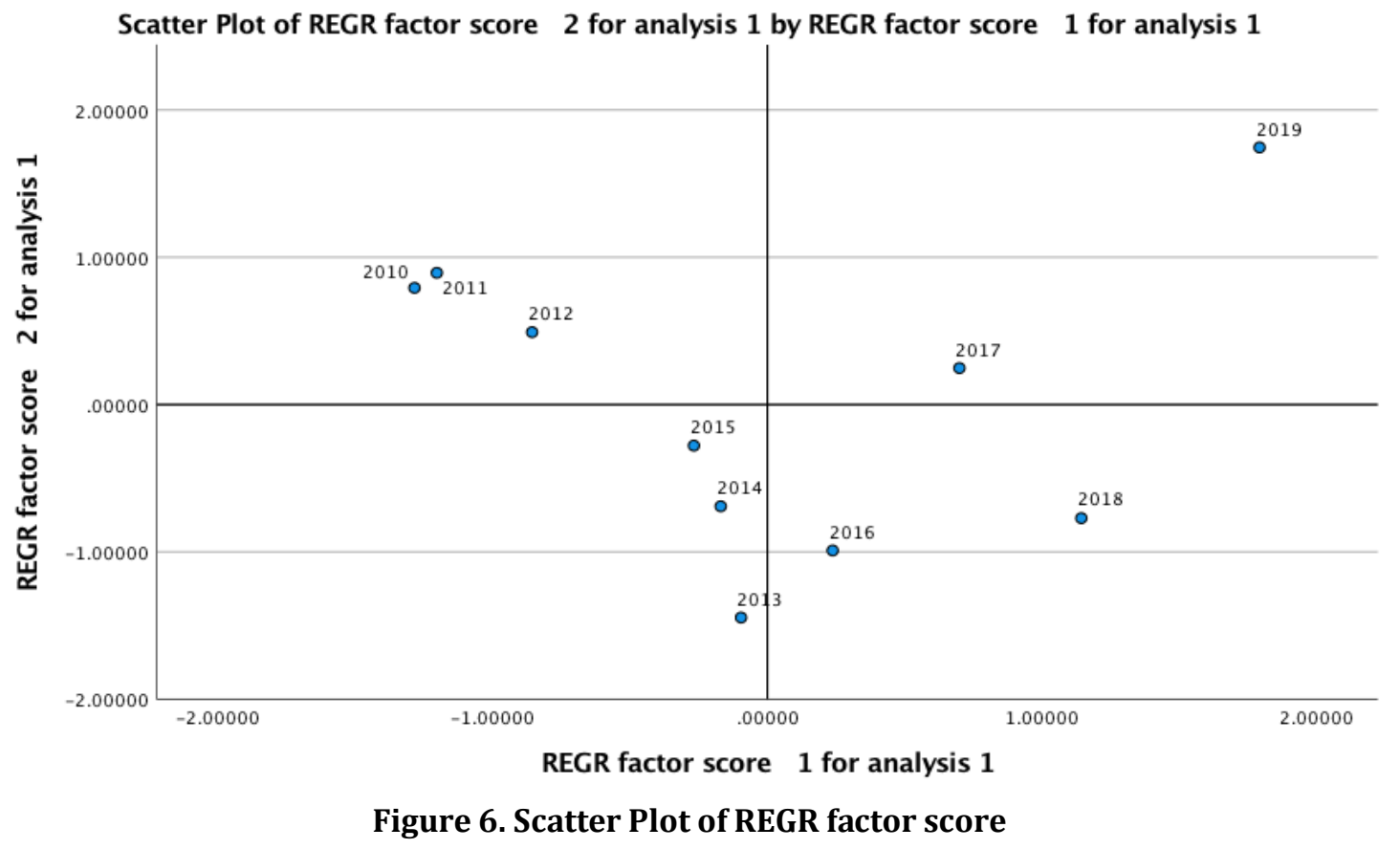

As can be seen in this diagram, there is a very clear difference between the values of the indicators recorded in 2010, 2011, 2012, on the one hand and 2017, 2018, 2019, on the other. The differences are also supported by significant increases in financial indicators, fixed assets, shareholder's equity, receivables, and short-term debt. Following a general assessment of the subsector of support activities for enterprises, the conclusion that can be drawn is one of obvious evolution in the sense of a sustained financial profitability. Retaining the heterogeneity of the group and the strong connection between the support services of the analyzed enterprises and the specific practices of a responsible corporate attitude, the present analysis brings a distinct approach to the financial dimension of this suggestive group of activities. Deepening the factor analysis that contributed to these spectacular increases in the average indicators at the group level is of interest for future research. It would be interesting to analyze whether evolutions of similar significance can also be observed in other economic sub-activities at the level of Constanta city.

\section{References}

1. Barnett, M.L., (2007). Shareholder influence capacity and the variability of financial re-turns to corporate social responsibility. Acad. Manag. Rev. 32 (3), 794-816. https:// doi.org/10.5465/amr.2007.25275520.

2. Barnett, M.L., Salomon, R.M., (2012). Does it pay to be really good? Addressing the shape of the relationship between social and financial performance. Strateg. Manag. J. 33, 1304-1320.

3. Barnett, M.L., Salomon, R.M., (2006.) Beyond dichotomy: the curvilinear relationship between social responsibility and financial performance. Strateg. Manag. J. 27, 1101-1122.

4. Bowman, E.H., Haire, M., (1975). A strategic posture toward corporate social responsibility. Calif. Manage. Rev. 28 (2), 49-58. https://doi.org/10.2307/41164638.

5. Carlos, W.C., Lewis, B.W., (2018). Strategic silence: withholding certification status as a hypocrisy avoidance tactic. Adm. Sci. Q. 63. https://doi.org/10.1177/000183921769508

6. Carroll, A., (1999). Corporate social responsibility: evolution of a definitional construct. Bus. Soc. 38 (3), $268-295$. https://doi.org/10.1177/000765039903800303

7. Carroll, A.B., Shabana, K.M., (2010). The business case for corporate social responsibility: a review of concepts, research and practice. Int. J. Manag. Rev. 12 (1), 85-105. https:// doi.org/10.1111/j.1468-2370.2009.00275.x

8. Eccles, R.G., Ioannou, I., Serafeim, G., (2014). The impact of corporate sustainability on organizational processes and performance. Manage. Sci. 60 (11), 2835-2857. https:// doi.org/10.1287/mnsc.2014.1984.

9. Farmaki, A., (2018). Corporate social responsibility in hotels: a stakeholder approach. Int. J. Contemp. Hosp. Manage.

10. Freeman, R.E., (1984). Strategic Management: A Stakeholder Approach. Prentice Hall, Englewood Cliffs, NJ. https://doi.org/10.2139/ssrn.263511.

11. Freeman, I., Hasnaoui, A., (2011). The meaning of corporate social responsibility: the vi- sion of four. J. Bus. Ethics 100 (3), $419-443$. https://doi.org/10.1007/s10551-010-0688-6.

12. Friedman, M., (1970). The Social Responsibility of Business is to Increase its Profits. NY Times 5: SM17.

13. Garay, L., Font, X., (2012). Doing good to do well? Corporate social responsibility reasons, practices and impacts in small and medium accommodation enterprises. Int. J. Hosp. Manag. 31 (2), 329-337. https://doi.org/10.1016/j.ijhm.2011.04.013.

14. Goffi, G., Masiero, L., Pencarelli, T., (2018). Rethinking sustainability in the tour-operating industry: worldwide survey of current attitudes and behaviors. J. Clean. Prod. 183, 172-182. https://doi.org/10.1016/j.jclepro.2018.02.029.

15. Iyer, G.R., Jarvis, L., (2019). CSR adoption in the multinational hospitality context: a re-view of representative research and avenues for future research. Int. J. Contemp. Hosp. Manage. 31 (6), 2376-2393. https://doi.org/10.1108/IJCHM-06-2018-0451.

16. Lubin, D., Esty, D.C., (2012). Bridging the sustainability gap. MIT Sloan Manage. Rev. 55 (4), 18-21.

17. Meier, S., Cassar, L., (2018). Stop talking about how CSR helps your bottom line. Harv. Bus. Rev. 1-6.

18. Munteanu, I. (2020a). "An Overview of the Business Approach and Labor Costs in the Construction Industry. Case Study: Romania's Counties by the Sea". Ovidius University Annals, Series Economic Sciences, 20(2). 
19. Munteanu, I., Mirea, M., (2017). "Efficiency in Corporate Governance-the Sustainability and Accountability Nexus". Ovidius University Annals, Economic Sciences Series, 17(1), 551-555.

20. Munteanu, I. (2020b). "Financial Reporting Quality and Operational Efficiency in the Coastal Region of Romania". Ovidius University Annals, Series Economic Sciences, 20(2).

21. Park, S.Y., Lee, S., (2009). Financial rewards for social responsibility: a mixed picture for restaurant companies. Cornell Hosp. Q. 50 (2), 168-179. https://doi.org/10.1177/1938965509331814.

22. Russo, A., Perrini, F., (2010). Investigating stakeholder theory and social capital: CSR in large firms and SMEs. J. Bus. Ethics 91 (2), 207221. https://doi.org/10.1007/s10551-009-0079-z.

23. Salancik, G.R., Pfeffer, J., (1978). A social information processing approach to job attitudes and task design. Adm. Sci. Q. 23 (2), $224-253$. https://doi.org/10.2307/2392563.

24. Theodolites, B., Diaz, D., Crotto, F., Rancati, E., (2017). Exploring corporate social responsibility and financial performance throughstakeholder theory in the tourism industries. Tour. Manag. 62, 173-188.

25. Wang, Z., Sarkis, J., (2017). Corporate social responsibility governance, outcomes, and financial performance. J. Clean. Prod. 162,16071616. 